\title{
The Development of Tissue-Engineered Grafts for Reconstructive Cardiothoracic Surgical Applications
}

\author{
TAMAR L. MIRENSKY AND CHRISTOPHER K. BREUER \\ Department of Surgery, Yale-New Haven Hospital, New Haven, Connecticut 06520
}

\begin{abstract}
Surgical correction of congenital heart defects often requires the use of valves, patches, or conduits to establish anatomic continuity. Homografts, xenografts, or mechanical prosthetic devices are frequently implanted during these surgical procedures. These grafts however lack growth potential, are associated with increased risk of thrombosis and infection and have limited durability, thus increasing the morbidity and mortality of their application in pediatric cardiac surgery. These limitations are being addressed through the development of living, biologic tissue-engineered valves, patches, and conduits. Pilot studies and phase 1 clinical trials are currently underway to evaluate their feasibility, safety, and efficacy. The optimal scaffold, cell source, and conditioning parameters, however, still remain to be determined and are areas of active research.
\end{abstract}

(Pediatr Res 63: 559-568, 2008)

$\mathrm{C}$ ongenital heart defects (CHDs) occur in $0.8 \%$ of all live births in the United States (1). Although some cardiac defects are clinically irrelevant, others are associated with significant morbidity and mortality. In North America, CHDs remain the leading cause of death among infants (2). Although medical therapy alone successfully supports cardiac function in some patients with cardiac defects, many complicated CHDs require surgical correction to establish anatomic continuity and physiologic restoration of flow (3). It has been estimated that less than half of all CHDs (0.3-0.4\% of all live births) are of surgical interest (4). Surgical correction of CHDs is generally reserved for cases in which other forms of therapy cannot maintain adequate circulation or the structural defects pose a threat to the development of the heart, lungs, or other organs. The form of surgical repair depends on the anatomic defects present, physiologic aberrances, and clinical presentation.

Following the first ligation of a patent ductus arteriosus in 1938 by Robert Gross, the field of pediatric cardiac surgery was born (5). The first open heart surgery was completed by Lewis in 1953 at which time he repaired an atrial septal defect under direct vision by inducing cardioplegia using hypothermia (6). John Gibbon was instrumental in further advancing this area of surgery with the introduction of a heart-lung machine that was described in 1954, which allowed for car-

Received November 1, 2007; accepted December 13, 2007.

Correspondence: Tamar Mirensky, M.D., Department of Surgery, Yale-New Haven Hospital, 330 Cedar Street, FMB 102, New Haven, Connecticut 06520; e-mail: tamar.mirensky@yale.edu

This work was supported by American Pediatric Surgical Association Foundation Research Fellowship; American Surgical Association Foundation Research Fellowship; Doris Duke Clinical Scientist Development Award; National Institute of Health K08HL83980. diopulmonary bypass during open-heart surgery and was first used during the repair of a large atrial-septal defect (7). Using hypothermic cardioplegia to induce intraoperative cardiac arrest in conjunction with cardiopulmonary bypass allowed for improved visualization of cardiac defects, increased accuracy in diagnosis of such defects, and successful intracardiac repair (8). With the introduction of the Blalock-Taussig shunt in 1944 (9) and the Fontan procedure in 1971 (10), oxygen poor systemic blood could be redirected to the pulmonary system, allowing for repair of numerous complicated heart defects that result in cyanotic heart disease. Among these conditions are tetralogy of Fallot, hypoplastic left heart syndrome, pulmonary atresia, and tricuspid atresia. Although a relatively young field, pediatric cardiothoracic surgery, specifically repair of CHDs, has proven to be a rapidly advancing area of medicine. Implementing many techniques of cardiothoracic surgery developed over the last century, surgeons today are attempting to repair even the most complex congenital defects to improve patient survival, minimize morbidity, and improve quality of life.

Congenital structural anomalies of the heart may affect any parts of the atria, ventricles, outlets, and/or great vessels. Although primary repair of defects is sometimes possible, implementation of prosthetic replacement grafts has allowed for establishment of anatomic continuity and physiologic restoration in more complicated cases. The Fontan procedure often involves implantation of prosthetic conduits that connect the right atrium to the pulmonary artery directly when tricuspid atresia and/or pulmonary atresia are present (10). In addition, patients afflicted by coarctation of the aorta may require implantation of a prosthetic conduit or patch to connect the left ventricle with the aorta distal to the site of coarctation. Patients with a diagnosis of tetralogy of Fallot may require implantation of a prosthetic conduit to restore blood from the right heart to the pulmonary system and/or placement of a prosthetic valve to repair a stenosis. Patients with large atrial-septal defects or ventricular-septal defects may require implantation of prosthetic patches during repair. Although these grafts may be life saving, they have limited durability and are prone to infection, immunologic reactivity, and thrombosis, which often requires repeat operations in the

\footnotetext{
Abbreviations: CHDs, congenital heart defects; IVC, inferior vena cava; P4HB, poly-4-hydroxybutyrate; P(CL/LA), $\epsilon$-caprolactone and lactide acid copolymer; PGA, polyglycolic acid; PGLA, polyglycolic acid and polylactic acid copolymer; PHO, polyhydroxyoctanoate
} 
future. Of particular concern in the pediatric population is the lack of growth potential of these currently available grafts.

Clinically significant aortic valve stenosis may be surgically repaired via a procedure described by Ross in 1967 (11). This procedure involves replacement of the stenosed aortic valve with a pulmonary autograft and subsequent replacement of the pulmonary valve with a prosthetic valve or homograft. Use of a pulmonary autograft into the aortic position provides a graft that grows as the patient grows, allows for favorable hemodynamics, frees a patient from the risk of anticoagulation, has limited infectious potential and does not contain foreign material thereby eliminating the risk of immunologic reactivity. The success of the Ross procedure is in part due to the success of the pulmonary autograft as it acts as an ideal valve replacement in the aortic position. A valvular graft placed into the pulmonary position does not develop dysfunction as readily as that in the aortic position. In addition, dysfunction of a valve in the pulmonary position is better tolerated that in the aortic position because of the lower pressures in the right heart and lower resistance in the pulmonary system. Many of the replacement valves placed into the pulmonary position, however, have limited durability and often require subsequent replacement. Depending on the type of replacement valve implanted, patients may be at an increased risk of endocarditis, thromboembolic events, bleeding effects of anticoagulation, calcification, and/or transmission of infections. It should also be noted that the Ross procedure potentially creates pulmonary valve disease in a previously healthy valve and treats a single valve disease with a two-valve procedure. Thus, failure of this procedure now places the patient at risk for repair of two valves.

To address both the limitations of grafts currently used as well as donor organ tissue scarcity, tissue-engineering applications have emerged to provide alternate solutions (12). Tissue engineering is an interdisciplinary field that integrates work in the fields of medicine, engineering, and biologic sciences. One tissue engineering strategy for creating neotissue is based on seeding a scaffold with biologic tissue (Fig. 1) (13). Following the work of Weinberg and Bell (14) in which blood vessels were constructed from bovine collagen scaffolds seeded with autologous cells, biodegradable polymers were later analyzed for the construction of tissueengineered grafts (Table 1). With the ability of seeded cells to remodel biodegrading scaffolds, tissue-engineered grafts have the potential to grow, self-repair, and develop into tissue similar in appearance and physiologic function to native tissue (15). Additionally, use of autologous cell sources may eliminate the risk of rejection and reduce the risk of thrombosis, thus increasing biocompatibility (3).

Surgical repair of CHDs using tissue-engineered grafts requires that these structures maintain certain properties. These grafts must integrate into the surrounding tissue, possess an acceptable healing response with limited inflammation and immunogenicity, remain nonthrombogenic and resist infection. An ideal graft should permit diffusion of nutrients and waste, enable cell adhesion, migration, proliferation and differentiation, and facilitate formation of the extracellular matrix and endothelial lining (16). Vascular grafts must also withstand

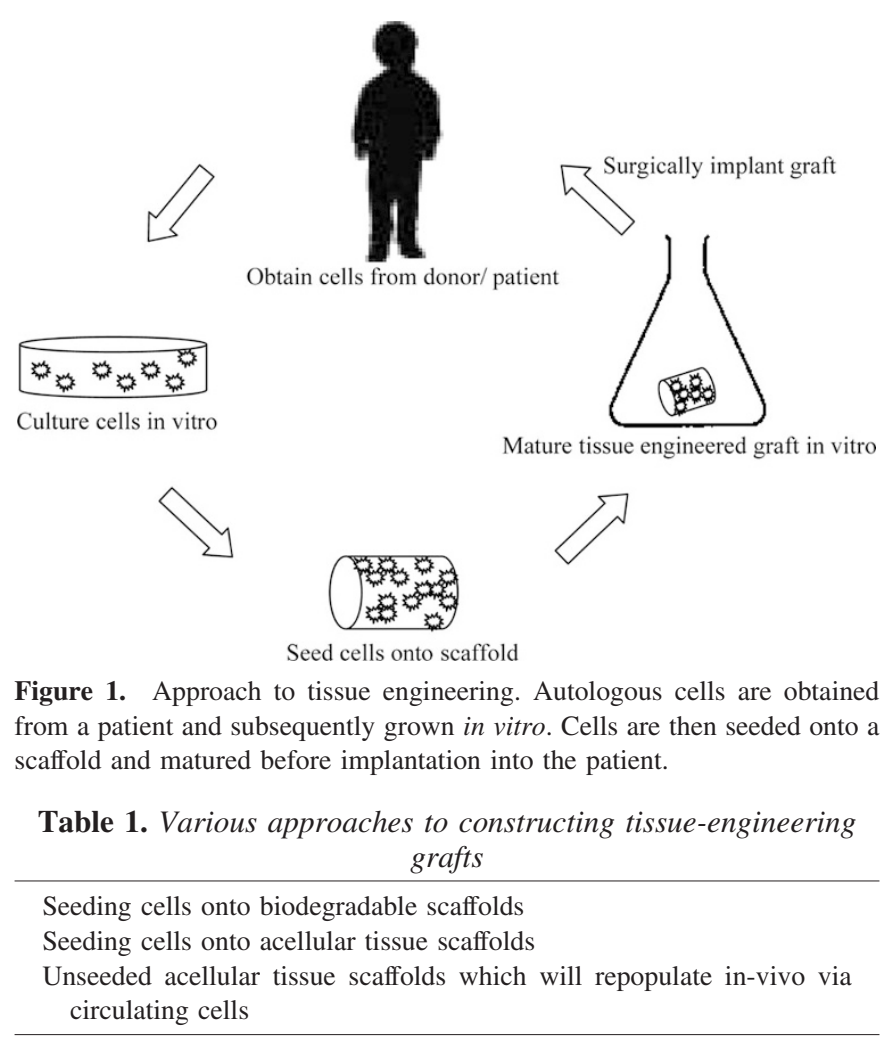

hemodynamic stresses while maintaining elasticity to prevent aneurysm formation and respond appropriately to constrictive or relaxation signals from hormones and pharmacologic agents in the circulatory system. Finally, clinical application of these grafts mandates that they be easily manipulated by surgeons and stable enough to hold suture material.

\section{TISSUE-ENGINEERED CARDIAC VALVES}

CHDs involving the valves of the heart can lead to the devastating effects of stenosis with outflow obstruction or regurgitation with loss of unidirectional blood flow. Stenosis leads to hypertrophy of the myocardium whereas regurgitation leads to volume overload. Mixing of oxygenated and deoxygenated blood causes chronic hypoxemia and cyanosis. Inefficiency of the cardiovascular system causes potentially lethal conditions if left untreated.

Since Hufnagel and Harvey first implanted a prosthetic valve in 1953, numerous types of prosthetic valves have been used to replace diseased valves (17). Currently, treatment for patients with valvular disease is heart valve replacement surgery using a mechanical prosthetic valve, glutaraldehyde-fixed xenograft, homograft, or autograft via the Ross procedure. Replacement valves can be life saving and often lead to improved quality of life; however, they are not without significant risks $(18,19)$. The relative strengths and weaknesses of these replacement valves have been identified (Table 2), thus allowing clinicians to best tailor selection of the graft to the individual. Caldarone et al. found that while younger age correlated with reduced time to valve replacement, diagnosis, type of prosthesis, and size of prosthetic valve also effect valve longevity (20). Mechanical valves are durable but are 
Table 2. Advantages and disadvantages of valvular grafts

\begin{tabular}{|c|c|c|}
\hline Valvular graft & Advantages & Disadvantages \\
\hline \multirow{4}{*}{$\begin{array}{l}\text { Mechanical } \\
\text { prosthesis }\end{array}$} & Durable & Thromboembolic events \\
\hline & Readily available & Hemolysis \\
\hline & Easy to handle & $\begin{array}{l}\text { Hemorrhage secondary to } \\
\text { anticoagulation }\end{array}$ \\
\hline & & No growth/remodeling \\
\hline \multirow{7}{*}{$\begin{array}{c}\text { Decellularized } \\
\text { xenograft }\end{array}$} & Readily available & Possibly immunogenic \\
\hline & Nonthrombogenic & Structural deterioration \\
\hline & $\begin{array}{l}\text { Decreased risk of } \\
\text { calcification }\end{array}$ & Infectious complications \\
\hline & & No growth/remodeling \\
\hline & & $\begin{array}{l}\text { Decellularization may alter } \\
\text { physical properties }\end{array}$ \\
\hline & & Must attract cells in vivo \\
\hline & & $\begin{array}{l}\text { Mechanism of cellular } \\
\text { attraction/adhesion } \\
\text { remains uncertain }\end{array}$ \\
\hline \multirow[t]{5}{*}{ Homograft } & Nonthrombogenic & Donor scarcity \\
\hline & Biocompatible & Calcification \\
\hline & & Structural deterioration \\
\hline & & Infectious complications \\
\hline & & No growth/remodeling \\
\hline \multirow{7}{*}{$\begin{array}{l}\text { Tissue-engineered } \\
\text { graft }\end{array}$} & Readily available & Labor intensive processing \\
\hline & Nonthrombogenic & $\begin{array}{l}\text { Function relies on } \\
\text { deposition of neotissue }\end{array}$ \\
\hline & Growth potential & Inflammatory response \\
\hline & Remodel in vivo & $\begin{array}{l}\text { Difficult to control cell } \\
\text { adhesion and tissue } \\
\text { reorganization }\end{array}$ \\
\hline & $\begin{array}{l}\text { Low infectious } \\
\text { risk }\end{array}$ & $\begin{array}{l}\text { Limited perfusion to deep } \\
\text { cells }\end{array}$ \\
\hline & Control structure & Scar tissue replaces graft \\
\hline & Control properties & \\
\hline
\end{tabular}

associated with an increased risk of thrombosis and hemolysis (21). Patients receiving mechanical valves must be maintained on anticoagulation $(22,23)$ with a risk of hemorrhagic complications (0.5-3.3 events/100 patient-years) (24) that poses a great danger in the pediatric population. Duran and Gunning described the first implantation of a heterologous valve into a dog in 1965 (25). This was subsequently followed by implantation into humans (26). Patients receiving such xenograft valves are at increased risk of infectious complications such as endocarditis and will require additional valve replacement surgeries because of graft degeneration and limited durability $(27,28)$. Pediatric patients have a higher incidence of homograft calcification (29) and accelerated rates of graft degeneration, which may be attributable to age-related immune mechanisms $(30,31)$. Although cryopreserved homografts are the most biocompatible replacement heart valve available, donor scarcity, transmission of infection and transplantassociated problems limit their use $(32,33)$.

Properties of native valves have been described in Table 3 . Ideal replacement heart valves should be durable, biocompatible, nonimmunogenic, nonthrombogenic, readily available, easy to handle, and have the potential to grow and remodel in vivo (Table 4) (34). These valves should not require anticoagulation and should be associated with a low risk of infectious complications (24). Tissue engineering principles have
Table 3. Properties of native valves
Unidirectional blood flow
Mechanical strength
Cellular viability
Growth
Repair/remodeling

Table 4. Properties of ideal replacement valves

Durable
Biocompatible
Nonimmunogenic/noninflammatory
Nonthrombogenic
Readily available
Easy to handle
Easy to implant
High suture retention strength
Ability to withstand high pressures
Growth potential
Remodel in vivo
Adequate mechanical function
Adequate hemodynamic performance
Flexible
Support cellular viability/proliferation
Support cellular attachment
Porous macrostructure (support cellular migration and waste removal)
Resorbable
Low infectious risk

been applied in the construction of an ideal replacement valve. Tissue-engineered valves may eliminate the need for additional operations and the morbidity and mortality associated with these procedures.

Tissue-engineered valves have been constructed by seeding biodegradable synthetic valve matrices, decellularized allografts or xenografts, or by implanting unseeded decellularized allografts (35). Scaffolds coated with an endothelial cell layer have better long-term patency rates than their unseeded counterparts (36). Scaffolds have been composed of various types of polymers or polymer combinations (Table 5). Cells seeded onto a scaffold also support neo-tissue formation. Cell sources have included vascular-wall derived cells, peripheral bloodderived cells, and bone marrow-derived cells (Table 6) (37). Use of autologous tissue may eliminate the risks of infection, rejection, hemolysis, and thrombosis (38). This would also eliminate the need for a tissue donor (39).

Tissue-engineered valves constructed from varying combinations of scaffolds and cell sources matured under differing growth conditions have been studied in both animal models and humans (40). Early work in the development of tissueengineered cardiac valves was completed by Breuer et al. (41). Tissue-engineered lamb heart valve leaflets were made by seeding a degradable synthetic polymer scaffold made from polyglycolic acid (PGA) and a copolymer of PGA and polylactic acid (PGLA) with myofibroblasts and large-vessel endothelial cells obtained from either the femoral or carotid arteries of 20-d-old lambs. These leaflets were then implanted into the donor lambs in the position of the native right posterior pulmonary valve leaflet. Although the polymeric scaffolds degrade by hydrolysis (over 6-8 wk), these scaffolds initially provide biomechanical strength and work together with the seeded cells to develop neo-tissue. Evaluation of the 
Table 5. Advantages and disadvantages of various biodegradable polymers used in tissue engineering

\begin{tabular}{|c|c|c|}
\hline $\begin{array}{l}\text { Biodegradable } \\
\text { polymer }\end{array}$ & Advantages & Disadvantages \\
\hline \multirow[t]{4}{*}{ PGA } & $\begin{array}{l}\text { Rapid degradation } \\
\quad(6-8 \text { wk) }\end{array}$ & $\begin{array}{l}\text { Lose mechanical strength at } \\
2-4 \mathrm{wk}\end{array}$ \\
\hline & Strength & Limited pliability \\
\hline & $\begin{array}{l}\text { Facilitates neotissue } \\
\text { formation }\end{array}$ & Increased graft thickness \\
\hline & FDA approved & $\begin{array}{l}\text { Does not maintain predefined } \\
\text { structure }\end{array}$ \\
\hline \multirow[t]{2}{*}{ PLA } & $\begin{array}{l}\text { Limits hydrolysis/ } \\
\text { degradation }\end{array}$ & $\begin{array}{l}\text { Poor substrate for cell growth } \\
\text { in vitro }\end{array}$ \\
\hline & FDA approved & \\
\hline PHA & Flexible & Prolonged degradation time \\
\hline $\mathrm{PHO}$ & Strength & Prolonged degradation time \\
\hline \multirow[t]{2}{*}{$\mathrm{P} 4 \mathrm{HB}$} & $\begin{array}{l}\text { Rapid degradation } \\
\quad(8 \mathrm{wk})\end{array}$ & $\begin{array}{l}\text { Limited cellular/collagen } \\
\text { uptake }\end{array}$ \\
\hline & Thermoplasticity & \\
\hline \multirow[t]{2}{*}{$\begin{array}{l}\text { Decellularized } \\
\text { allografts }\end{array}$} & $\begin{array}{l}\text { Limited immunologic } \\
\text { reactivity }\end{array}$ & Donor scarcity \\
\hline & Growth potential & Infectious complications \\
\hline $\begin{array}{l}\text { Decellularized } \\
\text { gluteraldehyde }\end{array}$ & Readily available & Infectious complications \\
\hline \multirow[t]{3}{*}{ Fixed xenografts } & Strength & Early structural deterioration \\
\hline & Durability & Limited pliability \\
\hline & $\begin{array}{l}\text { Limited immunologic } \\
\text { reactivity }\end{array}$ & Lacks growth potential \\
\hline
\end{tabular}

cardiac leaflet by two-dimensional echocardiography and color Doppler ultrasonography on postoperative days 1, 7, 14, and 21 demonstrated that although the tissue-engineered valves were thicker than the native leaflets and did not move as freely as native tissue, there was no evidence of stenosis or clinically significant regurgitation. Upon histologic evaluation of the leaflets, the seeded grafts demonstrated an extracellular matrix similar to that of native leaflets. On the other hand, lambs receiving unseeded grafts showed evidence of leaflet degradation with worsening regurgitation, eventually rendering the leaflets dysfunctional.

Using a similar degradable PGA and copolymer PGLA mesh, human dermal fibroblasts with bovine aortic endothelial cells or sheep myofibroblasts with sheep endothelial cells were seeded onto scaffolds (42). These grafts were implanted into sheep with histologic and immunohistologic evaluations conducted $14 \mathrm{~d}$ later. The endothelial cells formed a monolayer on the vessel lumen. Analysis revealed that the engineered valve leaflets were morphologically and histologically similar to native tissue, therefore supporting seeding of the valvular grafts.

Construction of trileaflet heart valves using PGA with PGLA was limited by cusp stiffness, thickness, and nonpliability (43). In response, Sodian et al. constructed a trileaflet prosthetic heart valve from a polyhydroxyalkanoate biodegradable polymer scaffold seeded with autologous ovine cells obtained from carotid arteries $(44,45)$. Following cell seeding, the valves matured in a bioreactor that provided pulsatile flow for 1,4 , and $8 \mathrm{~d}$. The seeded cells proliferated and formed a confluent layer oriented in the direction of flow. An extracellular matrix containing collagen also developed in the seeded grafts. On the other hand, grafts that had not been seeded failed to show appropriate tissue formation or collagen content comparable with that of native tissue. Previous work by Shinoka et al. confirmed that animals receiving tissueengineered pulmonary valve leaflets seeded with autologous cells developed less infectious complications and failed to show shrinkage or deterioration of the valves when compared with valves seeded with allogenic cells (43), therefore further supporting the use of autologous cells in the construction of tissue-engineered valves.

Additional studies using different copolymer combinations were conducted by Stock et al. in which valves and associated conduits were made from composite scaffolds of PGA and polyhydroxyoctanoates (PHO) (46). The constructs were seeded with autologous ovine cells, incubated, and implanted in sheep to replace both the native pulmonary valve and main pulmonary artery. The sheep did not receive postimplantation anticoagulation. These valves were evaluated by echocardiography, histology and biochemical analysis at time points ranging from 1 to $24 \mathrm{wk}$. The seeded grafts remained patent throughout the study and demonstrated viable cells, which formed an organized structure containing an endothelial cell lining. The unseeded control valve, however, developed thrombus at $4 \mathrm{wk}$ postimplantation. Neither group of valves showed growth over the study period. Although PGA was completely degraded by $24 \mathrm{wk}$, the conduits continued to demonstrate PHO. Residual PHO likely contributes to lack of growth of the conduit during the 24-wk period, thus limiting clinical applicability in pediatric patients.

To address the limiting factor of prolonged scaffold degradation time, Hoerstrup et al. studied a composite pulmonary valve scaffold made of PGA coated with a rapidly bioabsorb-

Table 6. Advantages and disadvantage of various cell sources used in tissue engineering

\begin{tabular}{cll}
\hline \multicolumn{1}{c}{ Cell source } & \multicolumn{1}{c}{ Advantages } & \multicolumn{1}{c}{ Disadvantages } \\
\hline Bone marrow stem cells & Easy to obtain & Difficult to control cell differentiation \\
& Readily available & Mechanisms of differentiation \\
& Extensive in vitro proliferation & Processes are poorly understood \\
& Differentiate into various tissues & \\
& May be autologous cells & \\
Vascular derived cells & Autologous cells & Invasive procedures to obtain cells \\
& Often available in pediatric patients and patients & Not available in patients with vascular disease, \\
& without vascular disease & atherosclerosis, surgically absent vessels \\
& Easy to obtain & Slower proliferation than bone marrow cells \\
& Readily available & \\
& Autologous cells & \\
\hline
\end{tabular}


able polymer, poly-4-hydroxybutyrate (P4HB) (47). The scaffolds were seeded with autologous lamb cells and conditioned in a bioreactor, which provided both pressure and flow to promote mechanical strength and modulate cellular function $(48,49)$. These valves were implanted into the donor lambs and evaluated histologically and mechanically at day 1 and at $4,6,8,16$, and $20 \mathrm{wk}$. By 8 wk postimplantation, complete degradation of the polymer scaffold was seen. Explanted valves evaluated at later time points demonstrated layered neo-tissue, a partial endothelial cell lining and an extracellular matrix similar to that of native valves. Mechanical properties of the explanted valves resembled those of native tissue at the corresponding time courses. Additionally, there was no evidence of thrombus formation or stenosis of the prosthetic valves. Comparison studies between P4HB and PGA valvular scaffolds showed that PGA took up more cells and formed greater amounts of collagen than $\mathrm{P} 4 \mathrm{HB}$, thereby limiting the use of $\mathrm{P} 4 \mathrm{HB}$ (50).

To overcome the limitations associated with polymeric scaffolds, decellularized xenograft scaffolds were studied. Removing the cellular components from native valves leaves behind the extracellular matrix of the natural valves. It is unclear, however as to the effects of the decellularization process on the biomechanical properties of the tissue. Initially, these valves were fixed in formaldehyde; however, these did not have long-term success secondary to graft instability $(51,52)$. As a result, the glutaraldehyde-fixed valve was developed and first implanted in $1971(53,54)$. Glutaraldehyde fixation leads to cross-linking of the extracellular matrix proteins, which provides a sterile scaffold with reduced antigenic potential. Although glutaraldehyde-fixed xenografts are associated with decreased immunologic recognition by human recipients and are more stable than their unfixed counterparts, these grafts are associated with significant drawbacks. Cytotoxicity of the fixatives (i.e., glutaraldehyde) often precludes adequate endothelialization of the grafts (55). Glutaraldehyde cross-linked valves lack cellular viability or the ability for growth or remodeling. These grafts are also stiffer than native tissue $(41,45)$. Early work using these valves led to clinical cardiovascular deterioration as a result of prosthetic thrombotic stenosis, valve degeneration, and endocarditis which developed at late postoperative time points (56). In several cases of failed valves, the xenografts demonstrated stenosis secondary to fibrin deposition $(57,58)$. Despite this, the risk of thrombosis remains lower than in those patients receiving mechanical valves. Therefore, recipients of these valves do not typically require anticoagulation therapy. Additionally, improved antibiotics have reduced the infectious complications associated with xenograft implantation. The risk of early structural deterioration of the fixed xenografts in younger patients remains significant. Early work using these replacement glutaraldehyde-fixed porcine valves showed a significant number of pediatric recipients with accelerated calcification of the valve cusps that led to severe stenosis and regurgitation $(59,60)$. Progressive deterioration of the valves leads to collagen disruption and calcification that ultimately results in graft failure and necessitates eventual replacement of the grafts. Although studies comparing porcine valve replacements with mechanical valve replacement in the pediatric population demonstrated superior outcomes when receiving xenografts, these valves are plagued by limitations that leave us searching for an ideal replacement valve (61).

Goldstein et al. devised tissue-engineered heart valves (SynerGraft porcine heart valves, CryoLife Inc., Kennesaw, GA) from acellular composite porcine aorta, noncoronary aortic leaflet and anterior mitral leaflet with the goal of addressing the problems of graft stiffness, limited growth potential, and limited durability of glutaraldehyde-fixed xenograft heart valves (62). Goldstein's valves were designed to provide optimal performance with decreased immunogenic potential while maintaining the ability to grow, repair, and remodel. Three tissue-engineered valve leaflets were attached to a single root and subsequently implanted into sheep in the pulmonary valve position and into humans in the aortic or pulmonary valve position. These porcine leaflets demonstrated recellularization with the development of fibroblasts and myofibroblasts similar to those found in native leaflets. Although previous animal studies of implanted allogenic acellular matrix scaffolds seeded with autologous cells demonstrated subvalvular muscular calcification extending to the valve leaflet base in one animal (63), evaluation of the SynerGraft valves failed to show stenosis or significant calcification in any of the animal models. When implanted into four male children with CHDs, however, the results were devastating (64). Of the four children who received these valves, three died within $1 \mathrm{y}$ of receiving the graft and the fourth child underwent prophylactic removal of the valve. Histologic examination of the failed valves demonstrated fibrous hyperplasia without cell repopulation or endothelialization. The recipients underwent strong inflammatory responses to the xenogenic collagen matrix leading to graft degeneration and structural valve failure.

Dohmen et al. described the first human implantation of a tissue-engineered heart valve (Fig. 2) made from decellularized pulmonary allograft seeded with autologous vascular endothelial cells obtained from a forearm vein $4 \mathrm{wk}$ before implantation (65). This valve was implanted in a human in the pulmonary position during the Ross procedure. Postoperatively, the recipient had slight regurgitation (which remained stable at 1 y follow-up) with a normal functioning valve that

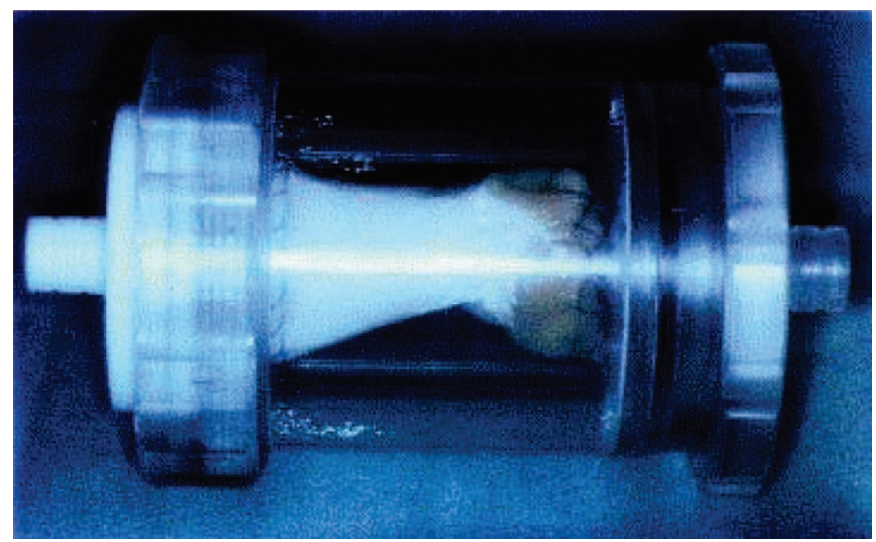

Figure 2. A bioreactor containing a tissue-engineered valve, which is attached at both ends to facilitate cell seeding. Reprinted from Dohmen et al. Ann Thorac Surg 74:1438-1442, Copyright (C) 2002 The Society of Thoracic Surgeons Published by Elsevier Inc., with permission. 
lacked calcification. Similar results were found when the same group implanted their valve into the pulmonary position of another patient during the same procedure (66). Although both patients seemed to have undergone clinical improvement following their operations, the amount of time necessary to construct such a valve makes it less likely to be useful in the perinatal period or in the case of life-threatening CHDs for which immediate repair is necessary.

Constructing a graft with a readily available cell source is advantageous for cases in which an extended graft preparation period is not possible. Such a source includes cells obtained from peripheral blood. Implantation of decellularized human pulmonary allograft heart valves seeded with autologous endothelial progenitor cells obtained from peripheral blood was first reported by Cebotari et al. (38). Following conditioning of the seeded allografts in a bioreactor for $21 \mathrm{~d}$, the valves were implanted into two pediatric patients with tetralogy of Fallot and associated pulmonary valvular disease. At 3.5 y postimplantation, there was no evidence of valve degeneration. Both patients initially had pulmonary regurgitation following their surgeries; however, the diameter of the pulmonary valve annulus increased proportionately as the child grew leading to resolution of regurgitation. At follow-up, both children continued to show normal somatic growth without limitations of physical activity or cardiac arrhythmias.

Although preliminary short-term data for the development of tissue-engineered valves are encouraging, much work remains to be completed in the construction of an ideal graft. Obtaining autologous cells for seeding from recipient patients requires invasive procedures to access these cells, additional hospitalizations and increased risks of complications. Additionally, cells that are cultured in xeroserum during preparation present risk of immunogenic reaction upon implantation. With the recent use of autologous bone marrow cells and mononuclear cells from peripheral blood, some of these concerns have been addressed. Additionally, the tissueengineered valves that have been studied thus far have been implanted into low-pressure systems. Application of these valves in a high-pressure system is still pending. Although great strides in the field of valvular tissue engineering have been made, continued efforts will enable development of viable, self-remodeling valvular substitutes with growth potential for further application in repair of CHDs.

\section{TISSUE-ENGINEERED CARDIOVASCULAR PATCHES}

Many cardiac defects require complex reconstruction of the heart and associated pulmonary and systemic connections. Repair of complete atrial-ventricular septal defects, augmentation of a hypoplastic, stenotic right ventricular outflow tract, or repair of tetralogy of Fallot often use nonautologous constructs, such as patches. Available patches include autologous pericardium, knitted polyester, Gore Tex (polytetrafluoroethylene), and bovine pericardium. Shortcomings of these patches include the inability to grow, remodel, and regenerate as well as increased risk of infection and aneurysm. These constructs are also subject to obstructive tissue ingrowth and fibrotic responses with shrinkage and calcification leading to graft failure (67). Autologous pericardium is difficult to handle $(68,69)$ while synthetic patches are associated with thromboembolic complications, hemolysis, and infective endocarditis $(70,71)$. Although flexible, strong, and easy to handle, bovine pericardium may be associated with graft calcification and contraction $(72,73)$.

Upon repair of CHDs using Dacron patches, presence of the foreign body induced a scar tissue healing response with contracture of the implant subsequently necessitating reoperation (74). Clinical studies using tissue-engineered vascular patches, however, have failed to show evidence of such an inflammatory response (39). This is likely the result of degradation of the polymer scaffold, leaving behind only autogenous neo-tissue. One group also observed that Dacron grafts were associated with prosthetic thickening and stiffness (75). In addition, the same study analyzing Dacron patches in the repair of CHDs, demonstrated tissue growth originating from the edges of the implanted graft with the center region of patches larger than $2.5 \mathrm{~cm}$ in width lacking tissue (74). Absence of an endothelial layer in this region of repair may place a patient at increased risk of thrombus or vegetation formation (70). This is of particular concern, as we know that thrombus formation often occurs in the presence of an unendothelialized foreign body. A tissue engineered patch designed in vitro, however, can be seeded with autologous endothelial cells so as to reduce the risk of thrombus formation.

One concern with tissue engineered cardiovascular patches is premature degradation of the polymer scaffold, leaving behind a weakened region of repair susceptible to aneurysmal dilatation. This is of particular concern for patch repairs exposed to high pressures. An advantage of tissue-engineered patches is the ability to control various properties of the graft, including scaffold degradation time. Utilization of different combinations of polymers and various scaffold preparation techniques enable researchers to develop patches with varying biomechanical and degradation profiles for numerous applications.

Tissue-engineered principles have been applied to the development of cardiac patches for repair of CHDs. Schmidt $e t$ al. used autologous human umbilical cord-derived fibroblasts and endothelial progenitor cells seeded on PGA/P4HB scaffolds to construct these patches (76). Endothelial progenitor cells obtained from human umbilical cord are readily available and can be harvested during the prenatal period (via ultrasound guided chordocentesis) making them an attractive cell source for tissue-engineered patches that require implantation in the immediate postnatal period. This would allow for treatment of CHDs diagnosed in utero. Following cell seeding, polymer scaffolds used in this model were conditioned in a bioreactor system for $27 \mathrm{~d}$ before implantation. All samples demonstrated evidence of layering of viable tissue. Collagen and proteoglycans were found in the extracellular matrix, with a higher content found in patches that had been conditioned with cyclic strain. The lumen contained endothelial cells and the newly formed tissue contained myofibroblasts. Mechanical properties of the tissue-engineered patches were similar to those of native analogous tissue; however, the patches failed to reach 
physiologic strength. These patches therefore are restricted to low-pressure systems such as the right ventricular outflow tract.

Bone marrow provides another cell source that is readily available and less invasive to obtain than cells from the walls of autologous blood vessels. These cells are also useful in patients who lack adequate blood vessels for harvest because of preexisting vascular disease or use in previous procedures or surgeries. Bone marrow cells differentiate into smooth muscle cells and endothelial cells (77-79). Cells found in the bone marrow can also differentiate into several cell types in vivo, which contribute to angiogenesis and vasculogenesis (80). Cho et al. constructed vascular patches by seeding autologous bone marrow-derived cells onto decellularized matrices obtained from the inferior vena cava (IVC) of dogs (81). Following differentiation of bone marrow mononuclear cells, they were seeded onto autologous matrices and implanted into canine models. Patch recipients did not receive postoperative anticoagulation or antiplatelet agents. Three weeks postimplantation, the grafts were explanted and analyzed histologically, immunohistochemically, and by electron microscope. Presence of endothelial cells, smooth muscle cells, collagen, and elastin were reported in the explanted constructs. All vascular patches remained patent without thrombus formation, thus supporting continued investigation of bone marrow as a cell source in the construction of tissueengineered grafts.

Tissue-engineered vascular patches constructed from autologous bone marrow mononuclear cells were first implanted into human patients in 2001 (82). Before using bone marrow cells, this group had implanted patches made from biodegradable scaffolds seeded with autologous cells that had been harvested from peripheral veins (83). Because harvesting peripheral veins is an invasive and lengthy procedure requiring additional hospitalization, this group sought aspiration of bone marrow to obtain a readily available cell source for seeding the tissue engineered polymer scaffolds. Bone marrow was aspirated on the day of surgery, which eliminated both the need for a donor and exposure to xeroserum during the cell culture process, thereby reducing the risks of rejection and infection and significantly decreasing the time for graft preparation from $4 \mathrm{wk}$ to less than $4 \mathrm{~h}$. The scaffolds prepared were comprised of either a PGA nonwoven fabric sheet or poly-Llactide (PLLA) mesh coated with a copolymer of lactide and $\epsilon$-caprolactone $(\mathrm{P}(\mathrm{CL} / \mathrm{LA}))$. The tissue-engineered patches were initially implanted into patients with defects of the pulmonary artery, however, were later extended to include a patient with a common atrium, which was separated by means of a tissue-engineered sheet. Since 2001, 19 tissue-engineered patches made of polymer scaffolds seeded with bone marrowderived cells have been implanted for repair of CHDs (39). Although histologic evaluation of implanted grafts in living human recipients is not possible, there has been no evidence of graft rupture, dilatation, calcification, thrombosis, stenosis, or obstruction as assessed by postoperative echocardiography, catheterization, computerized tomography, and/or magnetic resonance imaging. Lack of thrombus formation or stenosis, suggest that the remodeling process that occurs after patch implantation is well tolerated clinically. In addition, cellular proliferation and regeneration, and deposition of neo-tissue do not appear to adversely affect implantation of the tissueengineered patches. Unlike in procedures in which infective endocarditis follows implantation of synthetic patches, patient receiving tissue-engineered patches have not been afflicted by infective complications. These early results are promising in the application of tissue-engineered patches for repair of CHDs and warrant continued evaluation.

\section{TISSUE-ENGINEERED VASCULAR CONDUITS}

Conduit implantation for restoration of anatomic continuity between the ventricle and pulmonary artery was first described in 1964 by Rastelli et al. (84). In 1988, de Leval introduced the total cavopulmonary connection procedure which involved implantation of a conduit to join the systemic circulation to the pulmonary circulation (85). Since that time, reconstruction of complex CHDs involving abnormal pulmonary arteries and/or right ventricular outflow tracts have used conduits to reestablish anatomic continuity and physiologic blood flow (86). Conduits have been used in repair of pulmonary atresia, tetralogy of Fallot, transposition of the great arteries, truncus arteriosus, single ventricle physiology, and other complex anatomic defects (87). Conduits used for surgical repair of these abnormalities have included those made of Dacron (polyethylene terephthalate) or Gore-Tex (polytetrafluoroethylene), homografts and more recently, tissue-engineered conduits (88). Although in years past, prosthetic or bioprosthetic conduits had been used in the pediatric population, patient growth and progressive deterioration, and calcification of the replacement conduits led to stenosis and subsequent conduit failure $(30,89)$. Obstructed Dacron conduits have a fibrinous peel that develops in the lumen while homografts are often calcified at time of graft stenosis (89). The limited conduit lifespan necessitates repeat operations in pediatric recipients thereby making tissue-engineered conduits that grow, remodel, and regenerate an attractive alternative (90).

It has been hypothesized that low blood flow states increase susceptibility to thrombus formation in previously used prosthetic and bioprosthetic conduits (91). Others have attributed the increased risk of thrombus formation and stenosis/ obstruction of these conduits to deficiencies of thrombomodulin, increased fibrosis, neo-intimal hyperplasia, or calcification $(87,92)$. Tissue-engineered conduits that remodel in response to varying physiologic conditions would prove advantageous in that they may decrease the risk of thrombus formation. One major consideration, however, when developing tissueengineered conduits is that the rate of scaffold degradation must be balanced with that of neo-tissue formation so to minimize the risk of wall thinning or weakening and subsequent aneurysm formation. This is particularly true for conduits exposed to arterial pressures.

Tissue-engineered pulmonary arterial conduits made of acellularized ovine pulmonary arteries seeded with autologous endothelial cells from carotid arteries were implanted into immature, growing sheep by Leyh et al. (93). Unseeded acellular pulmonary conduits were implanted into control sheep. At 6 mo postimplantation, the pulmonary artery con- 
duits were retrieved from the study subjects. At this time period, neither group demonstrated evidence of thrombus formation or calcification. Histologic analysis revealed that the control specimens underwent degeneration of the extracellular matrix with reduced amounts of collagen and proteoglycans. The seeded conduits illustrated an increased cellularity within the extracellular matrix, resembling that of native ovine pulmonary artery. Increased cellularity may be the result of greater cell turnover; however, this needs to be further evaluated to ensure that fibrosis does not develop at a later time. Loss of conduit wall integrity seen in the control specimens placed these animals at increased risk of developing aneurysmal dilatation of the tissue-engineered conduits. Conduits that had been seeded with endothelial cells failed to show aneurysmal dilatation and instead demonstrated increases in diameter proportional to that of the native pulmonary arteries in the growing animals. Keeping in mind that currently used grafts lack growth potential, results of this study provide encouragement for the application of tissueengineered conduits in repair of CHDs in growing children.

Pulmonary artery segments were also replaced with tissueengineered conduits in growing lambs by Shinoka et al. (94). Similar to earlier work completed by this group in the application of tissue-engineered valves (41), the conduits were made of autologous myofibroblasts and endothelial cells that were seeded in vitro onto a PGA scaffold. Echocardiography and angiography confirmed that seeded grafts remained patent with nonaneurysmal increases in diameter, while control unseeded grafts developed thrombosis with subsequent occlusion as early as 2 wk postimplantation. Complete degradation of the polymer scaffold was seen by $11 \mathrm{wk}$. The remaining tissue resembled native pulmonary artery in collagen content and demonstrated elastic fibers and a luminal endothelial lining similar to those seen in native tissue. At the study conclusion, there was evidence of continued tissue remodeling of the grafts with a slight elevation of microscopic calcium content, though this was not found macroscopically.

Although not as critical in low-pressure systems, concerns have been raised over the rapid degradation of PGA scaffolds. It has been hypothesized that when placed into a high-pressure system, a rapidly degrading scaffold may place a recipient at risk of aneurysm formation. Therefore, tissue-engineered conduits made of a copolymer scaffold comprised of PGA and $\mathrm{P}(\mathrm{CL} / \mathrm{LA})$ were studied. These conduits were used to replace segments of the IVC in dogs (12). Characterization of the conduits in a low-pressure system enabled researchers to make necessary alterations for later application into a high-pressure system. The scaffolds were seeded with cells obtained from femoral veins of dogs that had been incubated for $7 \mathrm{~d}$ before implantation. There was no evidence of residual polymer scaffold at 3 mo postimplantation and none of the IVC replacement conduits showed occlusion or aneurysmal dilatation. One dog was observed for 13 mo at which time the IVC graft was without stenosis or occlusion. The grafts demonstrated endothelial cells that lined the luminal surfaces and extracellular matrix components that were comparable with native tissue.

Shinoka et al. later described the first implantation of vascular conduits into pediatric patients during repair of

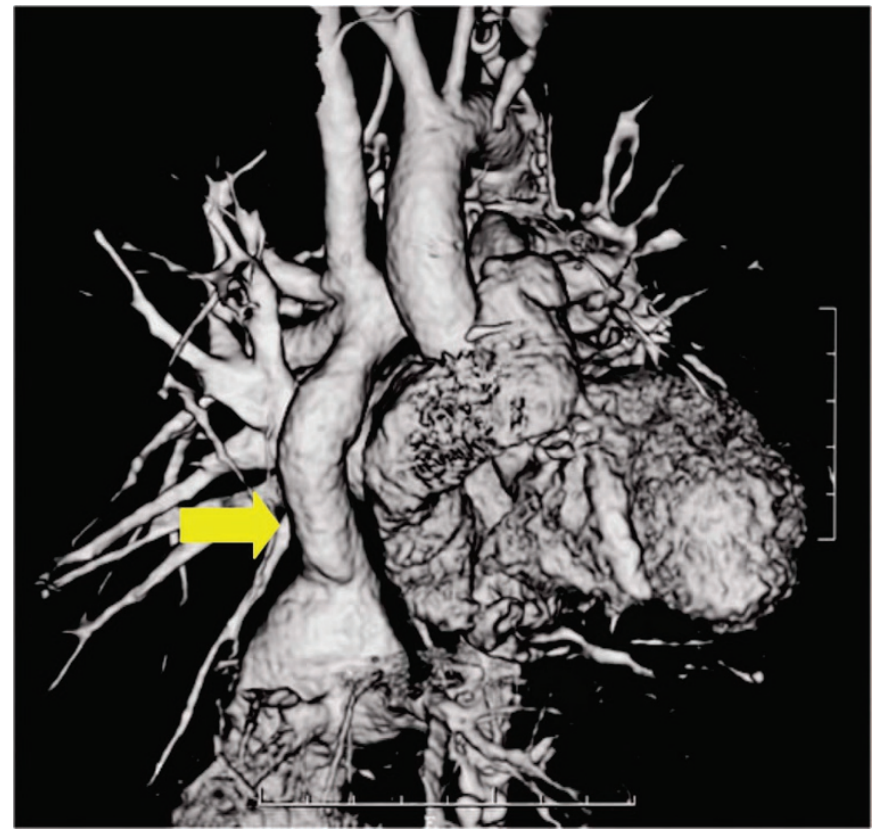

Figure 3. Yellow arrow highlights the tissue-engineered conduit connecting the inferior vena cava to the right pulmonary artery in a total cavopulmonary connection placed during repair of Tetralogy of Fallot. Reprinted from Shinoka et al. J Thorac Cardiovasc Surg 129:1330-1338, Copyright (C 2005 The American Association for Thoracic Surgery Published by Mosby, Inc., with permission.

CHDs (39). A PLLA with P(CL/LA) scaffold was seeded with cells harvested from the patient's own bone marrow on the day of surgery. The seeded conduits were placed in culture media for 2-4 h before implantation. The conduits were used to form extracardiac total cavopulmonary connections during repair of right ventricle outflow defects or single ventricle anatomy (Fig. 3) $(39,95)$. Doing this provided the pulmonary system with deoxygenated blood from the systemic system. As of June 2005, 23 tissue-engineered conduits had been implanted for repair of CHDs (39). Unlike the cases of tissue-engineered patches implanted by this group and previously described in this review, histologic evaluation was conducted on one conduit that had been implanted into a patient that later died for a reason unrelated to the graft placement. This conduit had remained patent and demonstrated endothelium-like cells on the graft lumen. All patients receiving tissue-engineered conduits were evaluated by echocardiography, angiography, computerized tomography, and/or magnetic resonance imaging. Patients who had received these conduits did not show evidence of graft thrombosis, stenosis, dilatation, rupture, or failure. Additionally, graft diameter was dependent on flow through the graft, with grafts placed in low flow systems showing decreases in diameter and those in high flow systems showing increases in diameter. This portrays one of the major advantages of tissue-engineered grafts in that growth and remodeling occur in response to the surrounding environment. Although we lack long-term follow-up for patients who have received tissue-engineered conduits, the results obtained thus far are encouraging. The preliminary data obtained to date supports continued research in this area and continued efforts in 
the development of tissue-engineered conduits for reconstructive cardiothoracic surgical applications.

\section{CONCLUSION}

The field of tissue-engineering cardiovascular structures for application in the repair of CHDs is young, yet rapidly progressive. We continue to search for optimal cells sources, scaffold matrices, and growth conditions when constructing grafts. Much data supports cell seeding in the assembly of tissue-engineered constructs; however, the fate and contribution of the seeded cells remain unknown. Immunoflourescent evaluation of tissue-engineered patches seeded with retrovirally labeled cells revealed presence of the seeded cells at $2 \mathrm{wk}$ postimplantation (96); however, the role of cells from adjacent native tissue and the role of circulating cells on scaffold-cell interactions and remodeling remain to be determined (97).

Currently, we lack long-term studies of tissue-engineered grafts that would allow for additional characterization of scaffolds used. The effects of combining cells with varying scaffold matrices under different growth conditions have not yet been identified. Many questions still remain unanswered in the field of tissue engineering of cardiovascular structures used in the repair of CHDs. Despite this, it is clear that the care of patients afflicted with CHD has been and will continue to be greatly influenced by further developments in tissue engineering.

\section{REFERENCES}

1. Green A 2004 Outcomes of congenital heart disease: a review. Pediatr Nurs 30:280-284

2. LeBlanc JG, Russell JL 1998 Pediatric cardiac surgery in the 1990s. Surg Clin North Am 78:729-747

3. Mayer JE, Shinoka T, Shum-Tim D 1997 Tissue engineering of cardiovascular structures. Curr Opin Cardiol 12:528-532

4. Zannini L, Borini I 2007 State of the art of cardiac surgery in patients with congenital heart disease. J Cardiovasc Med (Hagerstown) 8:3-6

5. Ohye RG, Bove EL 2001 Advances in congenital heart surgery. Curr Opin Pediatr 13:473-481

6. Lewis FJ, Taufic M 1953 Closure of atrial septal defects with the aid of hypothermia; experimental accomplishments and the report of one successful case. Surgery 33:52-59

7. Gibbon JH Jr 1954 Application of a mechanical heart and lung apparatus to cardiac surgery. Minn Med 37:171-185

8. Edmunds LH Jr 2002 The evolution of cardiopulmonary bypass: lessons to be learned. Perfusion 17:243-251

9. Blalock A, Taussig HB 1945 The surgical treatment of malformations of the heart in which there is pulmonary stenosis or pulmonary atresia. JAMA 128:189-202

10. Fontan F, Baudet E 1971 Surgical repair of tricuspid atresia. Thorax 26:240-248

11. Ross DN 1967 Replacement of aortic and mitral valves with a pulmonary autograft. Lancet 2:956-958

12. Watanabe M, Shin'oka T, Tohyama S, Hibino N, Konuma T, Matsumura G, Kosaka Y, Ishida T, Imai Y, Yamakawa M, Ikada Y, Morita S 2001 Tissue-engineered vascular autograft: inferior vena cava replacement in a dog model. Tissue Eng 7:429-439

13. Langer R, Vacanti JP 1993 Tissue engineering. (Methods of replacing or substituting for damaged or diseased tissues.) [Review]. Science 260:920-926

14. Weinberg CB, Bell E 1986 A blood vessel model constructed from collagen and cultured vascular cells. Science 231:397-400

15. Bader A, Steinhoff G, Strobl K, Schilling T, Brandes G, Mertsching H, Tsikas D, Froelich J, Haverich A 2000 Engineering of human vascular aortic tissue based on a xenogenic starter matrix. Transplantation 70:7-14

16. Ozawa T, Mickle DA, Weisel RD, Koyama N, Ozawa S, Li RK 2002 Optimal biomaterial for creation of autologous cardiac grafts. Circulation 106:I176-I182

17. Hufnagel CA, Harvey WP 1953 The surgical correction of aortic regurgitation preliminary report. Bull Georgetown Univ Med Cent 6:60-61

18. Breuer CK, Mettler BA, Anthony T, Sales VL, Schoen FJ, Mayer JE 2004 Application of tissue-engineered principles toward the development of a semilunar heart valve substitute. Tissue Eng 10:1725-1736

19. Rahimtoola SH 2003 Choice of prosthetic heart valve for adult patients. J Am Coll Cardiol 41:893-904
20. Caldarone CA, McCrindle BW, Van Arsdell GS, Coles JG, Webb G, Freedom RM, Williams WG 2000 Independent factors associated with longevity of prosthetic pulmonary valves and valved conduits. J Thorac Cardiovasc Surg 120:1022-1031

21. Yeo TC, Freeman WK, Schaff HV, Orszulak TA 1998 Mechanisms of hemolysis after mitral valve repair: assessment by serial echocardiography. J Am Coll Cardiol 32:717-723

22. Vongpatanasin W, Hills D, Lange RA 1996 Prosthetic heart valves. N Engl J Med 335:407-416

23. Hammermeister KE, Sethi GK, Henderson WG, Oprian C, Kim T, Rahimtoola S 1993 A comparison of outcomes in men 11 years after heart-valve replacement with mechanical valve or bioprosthesis. N Engl J Med 328:1289-1296

24. Sapirstein JS, Smith PK 2001 The "ideal" replacement heart valve. Am Heart J 141:856-860

25. Duran CG, Gunning AJ 1965 Heterologous aortic-valve transplantation in the dog. Lancet 1:114-115

26. Binet JP, Duran CG, Carpenter A, Langlois J 1965 Heterologous aortic valve transplantation. Lancet 2:1275

27. Jamieson WR, Tosado IJ, Munro AI 1988 Carpentier-Edwards standard porcine bioprosthesis. Primary tissue failure (structural valve deterioration) by age groups. Ann Thorac Surg 46:155-162

28. Schoen FJ, Levy RJ 1999 Tissue heart valves: current challenges and future research perspectives. Founder's Award, 25th Annual Meeting of the Society for Biomaterials, Providence, RI

29. Mayer JE 1995 Use of homograft conduits for right ventricle to pulmonary artery connection in the neonatal period. Semin Thorac Cardiovasc Surg 7:130-132

30. Albert JD, Bishop DA, Fullerton DA, Campbell DN, Clarke DR 1993 Conduit reconstruction of the right ventricular outflow tract: lessons learned in a twelve-year experience. J Thorac Cardiovasc Surg 106:228-236

31. Baskett RJ, Ross DB, Nanton MA, Murphy DA 1996 Factors in the early failure of cryopreserved homograft pulmonary valves in children: preserved immunogenicity. J Thorac Cardiovasc Surg 112:1170-1179

32. Fedalen PA, Fisher CA, Todd BA, Mather PJ, Addonizio P 1999 Early fungal endocarditis in homograft recipients. Ann Thorac Surg 68:1410-1411

33. O'Brien MF, Stafford EG, Gardner MA, Pohlner PG, Tesar PJ, Cochrane AD, Mau TK, Gall KL, Smith SE 1995 Allograft aortic valve replacement: long-term follow up. Ann Thorac Surg 60:s65-s70

34. Mayer JE 2001 In search of the ideal valve replacement device. J Thorac Cardiovasc Surg 122:8-9

35. Elkins RC 2002 Tissue-engineered valves. Ann Thorac Surg 74:1434

36. Pawlowski KJ, Rittgers SE, Schmidt SP, Bowlin GL 2004 Endothelial cell seeding of polymeric vascular grafts. Front Biosci 9:1412-1421

37. Perry TE, Roth SJ 2003 Cardiovascular tissue engineering: constructing living tissue cardiac valves and blood vessels using bone marrow, umbilical cord blood, and peripheral blood cells. J Cardiovasc Nurs 18:30-37

38. Cebotari S, Lichtenberg A, Tudorache I, Hilfiker A, Mertsching H, Leyh R, Breymann T, Kallenbach K, Maniuc L, Batrinac A, Repin O, Maliga O, Ciubotaru A, Haverich A 2006 Clinical application of tissue engineered human heart valves using autologous progenitor cells. Circulation 114:I132-I137

39. Shin'oka T, Matsumura G, Hibino N, Naito Y, Watanabe M, Konuma T, Sakamoto T, Nagatsu M, Kurosawa H 2005 Midterm clinical result of tissue-engineered vascular autografts seeded with autologous bone marrow cells. J Thorac Cardiovasc Surg 129:1330-1338

40. Mendelson K, Schoen FJ 2006 Heart valve tissue engineering: concepts, approaches, progress, and challenges. Ann Biomed Eng 34:1799-1819

41. Breuer CK, Shin'oka T, Tanel RE, Zund G, Mooney DJ, Ma PX, Miura T, Colan S, Langer R, Mayer JE, Vacanti JP 1996 Tissue engineering lamb heart valve leaflets. Biotechnol Bioeng 50:562-567

42. Zund G, Breuer CK, Shinoka T, Ma PX, Langer R, Mayer JE, Vacanti JP 1997 The in vitro construction of a tissue engineered bioprosthetic heart valve. Eur J Cardiothorac Surg 11:493-497

43. Shinoka T, Breuer C, Tanel R, Zund G, Miura T, Ma PX, Langer R, Vacanti JP, Mayer JE 1995 Tissue engineering heart valves: valve leaflet replacement study in a lamb model. Ann Thorac Surg 60:s513-s516

44. Sodian R, Hoerstrup SP, Sperling JS, Daebritz SH, Martin DP, Schoen FJ, Vacanti JP, Mayer JE 2000 Tissue engineering of heart valves: in vitro experiences. Ann Thorac Surg 70:140-144

45. Sodian R, Hoerstrup SP, Sperling JS, Daebritz S, Martin DP, Moran AM, Kim BS, Schoen FJ, Vacanti JP, Mayer JE Jr 2000 Early in vivo experience with tissueengineered trileaflet heart valves. Circulation 102:III22-III29

46. Stock UA, Nagashima M, Khalil PN, Nollert GD, Herden T, Sperling JS, Moran A, Lien J, Martin DP, Schoen FJ, Vacanti JP, Mayer JE 2000 Tissue-engineered valved conduits in the pulmonary circulation. J Thorac Cardiovasc Surg 119:732-740

47. Hoerstrup SP, Sodian R, Daebritz S, Wang J, Bacha EA, Martin DP, Moran AM, Guleserian KJ, Sperling JS, Kaushal S, Vacanti JP, Schoen FJ, Mayer JE Jr 2000 Functional living trileaflet heart valves grown in vitro. Circulation 102:III44-III49

48. Niklason LE, Gao J, Abbott WM, Hirsh KK, Houser S, Marini R, Langer R 1999 Functional arteries grown in vitro. Science 284:489-493

49. Hoerstrup SP, Sodian R, Sperling J, Vacanti JP, Mayer J 2000 New pulsatile bioreactor for in vitro formation of tissue engineered heart valves. Tissue Eng 6:75-79

50. Sodian R, Hoerstrup SP, Sperling JS, Martin DP, Daebritz S, Mayer JE, Vacanti JP 2000 Evaluation of biodegradable, three-dimensional matrices for tissue engineering of heart valves. ASAIO J 46:107-110

51. Hancock WD 1977 The porcine heart valve prosthesis. Med Instrum 11:102-103

52. Zuhdi N, Hawley W, Voehl V, Hancock W, Carey J, Greer A 1974 Porcine aortic valves as replacements for human heart valves. Ann Thorac Surg 17:479-491 
53. Carpentier A, Lemaigre G, Robert L, Carpentier S, Dubost C 1969 Biological factors affecting long-term results of valvular heterografts. J Thorac Cardiovasc Surg 58:467-483

54. Ionescu MI, Tandon AP, Mary DA, Abid A 1977 Heart valve replacement with the Ionescu-Shiley pericardial xenograft. J Thorac Cardiovasc Surg 73:31-42

55. Neuenschwander S, Hoerstrup SP 2004 Heart valve tissue engineering [Review]. Transpl Immunol 12:359-365

56. Fishbein MC, Gissen SA, Collins JJ Jr, Barsamian EM, Cohn LH 1977 Pathologic findings after cardiac valve replacement with glutaraldehyde-fixed porcine valves. Am J Cardiol 40:331-337

57. Johnson A, Thompson S, Vieweg WV, Daily P, Oury J, Peterson K 1978 Evaluation of the in vivo function of the Hancock porcine xenograft in the aortic position. J Thorac Cardiovasc Surg 75:599-605

58. Ashraf M, Bloor CM 1978 Structural alterations of the porcine heterograft after various durations of implantation. Am J Cardiol 41:1185-1190

59. Hellberg K, Ruschewski W, de Vivie ER 1981 Early stenosis and calcification of glutaraldehyde-preserved porcine xenografts in children. Thorac Cardiovasc Surg 29:369-374

60. Kutsche LM, Oyer P, Shumway N, Baum D 1979 An important complication of Hancock mitral valve replacement in children. Circulation 60:98-103

61. Sade RM, Ballenger JF, Hohn AR, Arrants JE, Riopel DA, Taylor AB 1979 Cardiac valve replacement in children: comparison of tissue with mechanical prostheses. J Thorac Cardiovasc Surg 78:123-127

62. Goldstein S, Clarke DR, Walsh SP, Black KS, O'Brien MF 2000 Transpecies heart valve transplant: advanced studies of a bioengineered xeno-autograft. Ann Thorac Surg 70:1962-1969

63. Steinhoff G, Stock U, Karim N, Martsching H, Timke A, Meliss RR, Pethig K, Haverich A, Bader A 2000 Tissue engineering of pulmonary heart valves on allogenic acellular matrix conduits: in vivo restoration of valve tissue. Circulation 102:III50-III55

64. Simon P, Kasimir MT, Seebacher G, Weigel G, Ullrich R, Salzer-Muhar U, Rieder E, Wolner E 2003 Early failure of the tissue engineered porcine heart valve SYNERGRAFTTM in pediatric patients. Eur J Cardiothorac Surg 23:1002-1006

65. Dohmen PM, Lembcke A, Hotz H, Kivelitz D, Konertz WF 2002 Ross operation with a tissue-engineered heart valve. Ann Thorac Surg 74:1438-1442

66. Gabbieri D, Dohmen PM, Linneweber J, Lembcke A, Braun JP, Konertz W 2007 Ross procedure with a tissue-engineered heart valve in complex congenital aortic valve disease. J Thorac Cardiovasc Surg 133:1088-1089

67. Endo S, Saito N, Misawa Y, Sohara Y 2001 Late pericarditis secondary to pericardial patch implantation 25 years prior. Eur J Cardiothorac Surg 20:1059-1060

68. Peter S 1999 Pericardial patch for atrial septal defect closure. Ann Thorac Surg 67:573-574

69. Mohri H, Barnes RW, Rittenhouse EA, Reichenback DD, Dillard DH, Merendino KA 1970 Fate of autologous pericardium and Dacron fabric used as substitutes for total atrial septum in growing animals. J Thorac Cardiovasc Surg 59:501-511

70. Shrivastava S, Radhakrishnan S 1989 Infective endocarditis following patch closure of ventricular septal defect: a cross-sectional Doppler echocardiographic study. Int J Cardiol 25:27-32

71. Di Eusanio M, Schepens MA 2002 Left atrial thrombus on a Teflon patch for ASD closure. Eur J Cardiothorac Surg 21:542

72. Pires AC, Saporito WF, Cardoso SH, Ramaciotti O 1999 Bovine pericardium used as a cardiovascular patch. Heart Surg Forum 2:60-69

73. Crawford FA Jr, Sade RM, Spinale F 1986 Bovine pericardium for correction of congenital heart defects. Ann Thorac Surg 41:602-605

74. Barros D'Sa AA, Berger K, Di Benedetto G, Parenzan L, Rittenhouse EA, Mansfield PB, Smith JC, Davis CC, Hall DG, Wood SJ, Sauvage LR 1980 A healable filamentous Dacron surgical fabric. Experimental studies and clinical experience. Ann Surg 192:645-657

75. Rittenhouse EA, Sauvage LR, Stamm SJ, Mansfield PB, Hall DG, Herndon PS 1979 Radical enlargement of the aortic root and outflow tract to allow valve replacement. Ann Thorac Surg 27:367-373

76. Schmidt D, Mol A, Neuenschwander S, Breymann C, Gossi M, Zund G, Turina M, Hoerstrup SP 2005 Living patches engineered from human umbilical cord derived fibroblasts and endothelial progenitor cells. Eur J Cardiothorac Surg 27:795-800
77. Wu KH, Cui B, Yu CT, Liu YL 2006 Stem cells: new cell source for myocardial constructs tissue engineering. Med Hypotheses 67:1326-1329

78. Wu K, Liu YL, Cui B, Han Z 2006 Application of stem cells for cardiovascular grafts tissue engineering. Transpl Immunol 16:1-7

79. Wu KH, Liu YL, Zhou B, Han ZC 2006 Cellular therapy and myocardial tissue engineering: the role of adult stem and progenitor cells. Eur J Cardiothorac Surg 30:770-781

80. McKay R 2000 Stem cells-the hype and hope. Nature 406:361-364

81. Cho SW, Park HJ, Ryu JH, Kim SH, Kim YH, Choi CY, Lee MJ, Kim JS, Jang IS, Kim DI, Kim BS 2005 Vascular patches tissue-engineered with autologous bone marrow-derived cells and decellularized tissue matrices. Biomaterials 26:1915-1924

82. Matsumura G, Hibino N, Ikada Y, Kurosawa H, Shin'oka T 2003 Successful application of tissue engineered vascular autografts: clinical experience. Biomaterials 24:2303-2308

83. Shin'oka T, Imai Y, Ikada Y 2001 Transplantation of a tissue-engineered pulmonary artery. N Engl J Med 344:532-533

84. Rastelli GC, Ongley PA, Davis GD, Kirklin JW 1965 Surgical repair for pulmonary valve atresia with coronary-pulmonary artery fistula: report of case. Mayo Clin Proc 40:521-527

85. De Leval MR, Kilner T, Gewillig M, Bull C 1988 Total cavopulmonary connection: a logical alternative to atriopulmonary connection for complex Fontan operations. Experimental studies and early clinical experience. J Thorac Cardiovasc Surg 96:682-695

86. Forbess JM 2004 Conduit selection for right ventricle outflow tract reconstruction: contemporary options and outcomes. Semin Thorac Cardiovasc Surg Pediatr Card Surg Annu 7:115-124

87. Tokunaga S, Kado H, Imoto Y, Masuda M, Shiokawa Y, Fukae K, Fusazaki N, Ishikawa S, Yasui H 2002 Total cavopulmonary connection with an extracardiac conduit: experience with 100 patients. Ann Thorac Surg 73:76-80

88. Dearani JA, Danielson GK, Puga FJ, Schaff HV, Warnes CW, Driscoll DJ, Schleck D, Ilstrup DM 2003 Late follow-up of 1095 patients undergoing operation for complex congenital heart disease utilizing pulmonary ventricle to pulmonary artery conduits. Ann Thorac Surg 75:399-410

89. Kay PH, Ross DN 1985 Fifteen years' experience with the aortic homograft: the conduit of choice for right ventricular outflow tract reconstruction. Ann Thorac Surg 40:360-364

90. Solomon NA, Pranav SK, Jain KA, Kumar M, Kulkarni CB, Akbari J 2006 In search of a pediatric cardiac surgeon's 'Holy Grail': the ideal pulmonary conduit. Expert Rev Cardiovasc Ther 4:861-870

91. Konstantinov IE, Puga FJ, Alexi-Meskishvili VV 2001 Thrombosis of intracardiac or extracardiac conduits after modified Fontan operation in patients with azygous continuation of the inferior vena cava. Ann Thorac Surg 72:1641-1644

92. Azakie A, McCrindle BW, Van Arsdell G, Benson LN, Coles J, Hamilton R, Freedom RM, Williams WG 2001 Extracardiac conduit versus lateral tunnel cavopulmonary connections at a single institution: impact on outcomes. J Thorac Cardiovasc Surg 122:1219-1228

93. Leyh RG, Wilhelmi M, Rebe P, Ciboutari S, Haverich A, Mertsching H 2006 Tissue engineering of viable pulmonary arteries for surgical correction of congenital heart defects. Ann Thorac Surg 81:1466-1471

94. Shinoka T, Shum-Tim D, Ma PX, Tanel RE, Isogai N, Langer R, Vacanti JP, Mayer JE 1998 Creation of viable pulmonary artery autografts through tissue engineering. J Thorac Cardiovasc Surg 115:536-546

95. Isomatsu Y, Shinoka T, Matsumura G, Hibino N, Konuma T, Nagatsu M, Kurosawa H 2003 Extracardiac total cavopulmonary connection using a tissue-engineered graft. J Thorac Cardiovasc Surg 126:1958-1962

96. Sales VL, Mettler BA, Lopez-Ilasaca M, Johnson J, Mayer JE 2007 Endothelial progenitor and mesenchymal stem cell-derived cells persist in tissue-engineered patch In vivo: application of green and red fluorescent protein-expressing retroviral vector. Tissue Eng 13:525-535

97. Rashid ST, Salacinski HJ, Fuller BJ, Hamilton G, Seifalian AM 2004 Engineering of bypass conduits to improve patency. Cell Prolif 37:351-366 